\title{
Morphological, ultrastructural, and molecular identification of a new microsporidian pathogen isolated from Crepidodera aurata (Coleoptera, Chrysomelidae)
}

\author{
Mustafa YAMAN ${ }^{1}$ YD , Gönül ALGI ${ }^{2}$ (D), Renate RADEK $^{3}$ (D) \\ ${ }^{1}$ Department of Biology, Faculty of Arts and Science, Bolu Abant İzzet Baysal University, Bolu, Turkey \\ ${ }^{2}$ Department of Biology, Faculty of Science, Karadeniz Technical University, Trabzon, Turkey \\ ${ }^{3}$ Institute of Biology/Zoology, Free University of Berlin, working group Evolutionary Biology, Berlin, Germany
}

Received: 03.02.2019

- Accepted/Published Online: 01.07 .2019

- Final Version: 02.09 .2019

\begin{abstract}
A new microsporidian pathogen isolated from Crepidodera aurata was identified based on morphological and ultrastructural characteristics, coupled with a molecular phylogenetic analysis. The spores of the microsporidian pathogen were slightly curved in shape, and measured 2.44-3.55 $\mu \mathrm{m}$ in length and $1.25-1.55 \mu \mathrm{m}$ in width $(\mathrm{n}=50)$. Its ultrastructure is characteristic of monokaryotic groups. All lifecycle stages of the pathogen, including meronts, sporonts, sporoblasts, and mature spores, are monokaryotic. The spore has 6-8 windings of the polar filament. Morphological and ultrastructural characteristics of the lifecycle stages place it within the family Unikaryonidae. However, the phylogenetic tree constructed on the 16S rRNA gene sequence analysis indicates that the pathogen is closely related to the Nosema/Vairimorpha clade of microsporidia. Therefore, we have classified the microsporidian of C. aurata in the tentative group Microsporidium in order to avoid creating an unnecessary or incorrect new genus/species.
\end{abstract}

Key words: Biological control, Crepidodera aurata, Chrysomelidae, new microsporidian pathogen

\section{Introduction}

The family Chrysomelidae (Coleoptera) is one of the largest families of beetles, including over 37,000 species in more than 2500 genera (Aslan et al., 1999; Urban, 2011). This family commonly includes widely distributed phytophagous insects. The literature shows that chrysomelids are frequently infected by entomopathogenic organisms (Poinar, 1988; Theodorides, 1988; Toguebaye et al., 1988). There is an increasing interest in isolating, identifying, and testing these pathogens for their potential as biological control agents (Hatakeyama, 2011; Yaman et al., 2010; Yaman et al., 2015; Holuša et al., 2016). Thus, several new microsporidian species have been isolated and characterized from these insects (Yaman and Radek, 2003; Yaman et al., 2008, 2010).

As a protist group, microsporidia are special eukaryotic, spore-forming organisms. They live only as obligate intracellular pathogens in eukaryotic systems. Their host range includes agricultural and forest pest insects, beneficial insects (honeybee, silkworm, predators, and parasitoids), fish, and ticks, as well as rodents, rabbits, and other fur-bearing mammals. Microsporidial taxa infecting agricultural and forest pest insects are preferable for biological control of pest insects. Among

\footnotetext{
*Correspondence: muyaman@hotmail.com
}

the entomopathogenic protists, microsporidia have been recognized for potential control of pest insects. Use of microsporidia in biological control is a very new approach in Turkey. Recently, Yaman et al. (2015) recorded two types of microsporidian isolates from Crepidodera aurata in Turkey, based on observations using light microscopy. In classification of microsporidia, electron microscopy and DNA-based molecular methods have become increasingly important. Additionally, rRNA gene sequences are another important parameter currently used in the classification of microsporidia. In the present study, we present a thorough morphological, ultrastructural, and molecular identification of one of the new microsporidian pathogens from C. aurata.

\section{Materials and methods}

\subsection{Light and electron microscopies}

Adult specimens of Crepidodera aurata were collected from two different populations in the area of Samsun (Turkey) where microsporidian infection had previously been found by Yaman et al. (2015). The density of beetles on young poplar trees was very high, and adults were collected using an aspirator. In total, 370 adult beetles were examined for possible parasites. During the light 
microscopy observation, both wet and Giemsa-stained slides were studied. For this, each insect was dissected in insect Ringer's solution to preserve vegetative forms of microsporidia. Possible food plugs were removed, and the slide was covered with a coverslip and inspected under the microscope. When spores of a microsporidian infection were observed in a wet smear, the excess water was removed using a paper wick and the slide was dried at room temperature. Air-dried specimens were fixed in methanol and stained with Giemsa-stain solution in a staining rack to study the developmental stages of the pathogens. After staining, the slides were rinsed with tap water and dried at room temperature. Giemsa-stained preparations were then carefully examined for other lifecycle stages such as meronts, sporonts, and sporoblasts.

The ultrastructure of the pathogen was studied with a Philips EM 208 transmission electron microscope (TEM) using standard preparation techniques (Yaman et al., 2011). In preparation, infected specimens were cut into smaller pieces $(1 \mathrm{~mm})$, transferred to fresh glutaraldehyde, and fixed for $2.5 \mathrm{~h}$ at room temperature. Specimens were then washed in $0.1 \mathrm{M}$ cacodylate buffer ( $\mathrm{pH} 7.2-7.3) 3$ times for 10 min each (30 min total) and postfixed in $2 \%$ osmium tetroxide for $1.5 \mathrm{~h}$. After postfixation, specimens were washed again in $0.1 \mathrm{M}$ cacodylate buffer $(\mathrm{pH} 7.2-$ 7.3) 3 times for $10 \mathrm{~min}$ each. For dehydration, specimens were transferred through an ascending alcohol series into absolute alcohol prior to embedding in Spurr's resin (Spurr, 1969). Thin sections were mounted on Pioloform-coated copper grids which were then stained with saturated with uranyl acetate and Reynolds' lead citrate (Reynolds, 1963).

2.2. Purification of microsporidia from infected insects Semipurified spore suspensions were used for DNA extraction. In the first step of preparation for extraction, heavily infected insects were dissected individually under a stereomicroscope, and infected tissues were removed from the insect bodies and collected in a 1.5-mL Eppendorf tube. The infected tissues were then homogenized with Ringer's solution in an Eppendorf tube using a micropestle. The homogenates were filtered through 3 layers of muslin to remove gross insect debris. A final solution was centrifuged to eliminate debris.

\subsection{Nucleic acid extraction, rRNA gene sequencing, and} phylogenetic analysis

Microsporidia in terrestrial hosts have a thick endospore. To make DNA isolation easier, ribosomal DNA was extracted by agitation of microsporidian spore with glass beads. The semipurified spore solution was diluted with distilled water, and an equal volume of spore suspension and glass beads were put into a new Eppendorf tube and vigorously shaken on the vortex for $1 \mathrm{~min}$ at maximum speed. The solutions were then incubated with proteinase $\mathrm{K}$ at $56{ }^{\circ} \mathrm{C}$ for $3 \mathrm{~h}$. Nucleic acid extraction was performed with a DNA isolation kit according to the manufacturer's guidelines and Hyliš et al. (2005). To amplify the microsporidian SSU rRNA genes, the $18 \mathrm{~F} / 1537 \mathrm{R}$ primer sets (18F/1537R: 5'-CACCA GGTTG ATTCT GCC-3'/5'TTATG ATCCT GCTAA TGGTT C-3') and PCR solution were used. The amplification was performed under the following conditions: after initial denaturation of DNA at $95^{\circ} \mathrm{C}$ for $15 \mathrm{~min}, 45$ cycles were run $\left(94^{\circ} \mathrm{C}\right.$ for $30 \mathrm{~s}, 61$ ${ }^{\circ} \mathrm{C}$ for $90 \mathrm{~s}$, and $72{ }^{\circ} \mathrm{C}$ for $90 \mathrm{~s}$ ) with a 10 min extension at $72{ }^{\circ} \mathrm{C}$. The PCR-amplified products were loaded onto a $0.9 \%$ agarose gel which was supplemented with ethidium bromide. The PCR products and the primers used for PCR were then sent for determination of the base sequences.

The GenBank accession numbers of microsporidian SSU rRNA gene sequences from 36 microsporidians used in the phylogenetic analysis are listed in Table 1. SSU rRNA gene sequences (Table 1) were aligned with maximum likelihood method using Kimura two-parameter distance and evaluated using 1000 bootstrap replications with the MEGA.6 program. The 36 SSU rRNA sequences belonging to various microsporidia species that produced the highest scores in the BLAST search were included in the analysis. Thelonia contejeani and Thelonia parastaci were used as outgroups in the analysis.

\section{Results}

In this study, a microsporidian pathogen from two populations in Samsun (Turkey) was investigated in detail using light and electron microscopy and molecular phylogenic analysis. The pathogen had been previously found in the same populations by Yaman et al. (2015), but had only been described using light microscopy. Hemolymph, Malpighian tubules, midgut, silk glands, and adipose body were the infection sites. The following features were observed under the light microscope: environmentally resistant, infective spores of the microsporidian pathogen were generally small, slightly curved, and measured $3.60 \pm 0.66(2.43-4.96) \mu \mathrm{m}$ in length and $1.72 \pm 0.31(1.08-2.37) \mu \mathrm{m}$ in width $(\mathrm{n}=50)$ (Figure 1). Meronts, sporonts, sporoblasts, and spores on Giemsa-stained slides always displayed one nucleus (Figures 2-4), and all stages were in direct contact with the host-cell cytoplasm. We did not observe any life stages in sporophorous vesicles (pansporoblasts) or parasitophorous vesicles; all mature spores were found as single cells (Figures 1 and 4). Sporogony ends with uninucleate single sporoblasts and spores (Figures 2 and 4). Giemsa-stained spores were $2.97 \pm 0.27 \mu \mathrm{m}$ in length and $1.61 \pm 0.21 \mu \mathrm{m}$ in width.

TEM revealed the very complex internal organization of the spore. We observed that spores have unpaired nuclei (no diplokarya) which are in direct contact with the hostcell cytoplasm, meaning that they are not produced in 
YAMAN et al. / Turk J Zool

Table 1. Species and GenBank accession numbers for the SSU rDNA sequences of 36 microsporidian species used in the phylogenetic analyses.

\begin{tabular}{|c|c|c|c|c|}
\hline Organism name & Access. No. & Host & Order & Family \\
\hline Anncaliia algerae & HM216911 & Homo sapiens & Primates & Hominidae \\
\hline Anncaliia meligethi & AY894423 & Meligethes aeneus & Coleoptera & Nitidulidae \\
\hline Cystosporogenes legeri & AY233131 & Lobesia botrana & Lepidoptera & Tortricidae \\
\hline Cystosporogenes operophterae & AJ302320 & Operophtera brumata & Lepidoptera & Geometridae \\
\hline Cystosporogenes sp. & AY566237 & Choristoneura fumiferana & Lepidoptera & \begin{tabular}{|l|} 
Tortricidae \\
\end{tabular} \\
\hline Endoreticulatus bombycis & AY009115 & Bombyx mori & Lepidoptera & Bombycidae \\
\hline Endoreticulatus schubergi & L39109 & - & ---- & ---- \\
\hline Endoreticulatus sp. CHW-2004 & AY502945 & Lymantria dispar & Lepidoptera & Erebidae \\
\hline Endoreticulatus sp. CHW-2004 & AY502944 & Ocinara lida & Lepidoptera & Bombycidae \\
\hline Endoreticulatus sp. CHW-2008 & EU260046 & Thaumetopoea processionea & Lepidoptera & Thaumetopoeidae \\
\hline Liebermannia covasacrae & EU709818 & Covasacris pallidinota & \begin{tabular}{|l|} 
Orthoptera \\
\end{tabular} & Acrididae \\
\hline Nosema apis & U97150 & Apis mellifera & Hymenoptera & Apidae \\
\hline Nosema bombi & AY008373 & Bombus terrestris & Hymenoptera & Apidae \\
\hline Nosema bombycis & AY259631 & \begin{tabular}{|l|l|}
$-\cdots--$ \\
$-\cdots$
\end{tabular} & & \\
\hline Nosema carpocapsae & AF426104 & Cydia pomonella & Lepidoptera & Tortricidae \\
\hline Nosema ceranae & DQ486027 & Apis mellifera & Hymenoptera & Apidae \\
\hline Nosema granulosis & AJ011833 & - & & \\
\hline Nosema oulemae & U27359 & Oulema melanopus & Coleoptera & Chrysomelidae \\
\hline Nosema plutellae & AY960987 & Plutella xylostella & Lepidoptera & Plutellidae \\
\hline Nosema spodopterae & AY747307 & Spodoptera litura & Lepidopterae & Noctuidae \\
\hline Nosema vespula & U11047 & Vespula germanica & Hymenoptera & Vespidae \\
\hline Paranosema grylli & AY305325 & - & - & $-\cdots$ \\
\hline Paranosema locustae & AY305324 & \begin{tabular}{|l}
$-\cdots--$ \\
\end{tabular} & \begin{tabular}{|l}
$-\cdots-$ \\
$-\cdots$
\end{tabular} & \begin{tabular}{|l}
$-\cdots$ \\
$-\cdots$
\end{tabular} \\
\hline Paranosema whitei & AY305323 & ----- & \begin{tabular}{|l|}
$-\cdots-$ \\
\end{tabular} & \begin{tabular}{|l}
$-\cdots-$ \\
--1
\end{tabular} \\
\hline Pleistophora hippoglossoideos & AJ252953 & Hippoglossoides platessoides & Pleuronectiformes & Pleuronectidae \\
\hline Pleistophora mulleri & EF119339 & Gammarus duebeni & Amphipoda & Gammaridae \\
\hline Pleistophora ovariae & AJ252955 & Notemigonus crysoleucas & Cypriniformes & Cyprinidae \\
\hline Pleistophora typicalis & AJ252956 & Myoxocephalus scorpius & Scorpaeniformes & Cottidae \\
\hline Thelohania contejeani & AF303105 & Astacus astacus & Decapoda & Astacidae \\
\hline Thelohania parastaci & AF294780 & Cherax destructor albidus & Decapoda & Parastacidae \\
\hline Thelohania solenopsae & AF134205 & Solenopsis invicta & Hymenoptera & Formicidae \\
\hline Vairimorpha imperfecta & AJ131646 & Plutella xylostella & Lepidoptera & Plutellidae \\
\hline Vairimorpha lymantriae & AF033315 & Lymantria dispar & Lepidoptera & Erebidae \\
\hline Vairimorpha necatrix & Y00266 & \begin{tabular}{|l|}
---- \\
\end{tabular} & \begin{tabular}{|l|}
$-\cdots--$ \\
\end{tabular} & \begin{tabular}{|l|}
$-\cdots--$ \\
\end{tabular} \\
\hline Unikaryonidae & JF960137 & Liophloeus lentus & Coleoptera & Curculionidae \\
\hline Microsporidium sp. (TR) & MF153501 & Crepidodera aurata & Coleoptera & Chrysomelidae \\
\hline
\end{tabular}

sporophorous or parasitophorous vesicles (Figures 5-10). Spores contain one spherical nucleus measuring 300-500 $\mathrm{nm}$ in diameter (Figures 5 and 9). Vacuolar space was observed at the posterior. The spore wall is thin (75-125 $\mathrm{nm}$ thick) and consists of a clear endospore (50 to 110 $\mathrm{nm})$ and an electron-dense, uniform exospore (25-30 nm) (Figures 5, 7, and 9). The internally coiled polar tube was the most diagnostic feature of the pathogen. The polar 

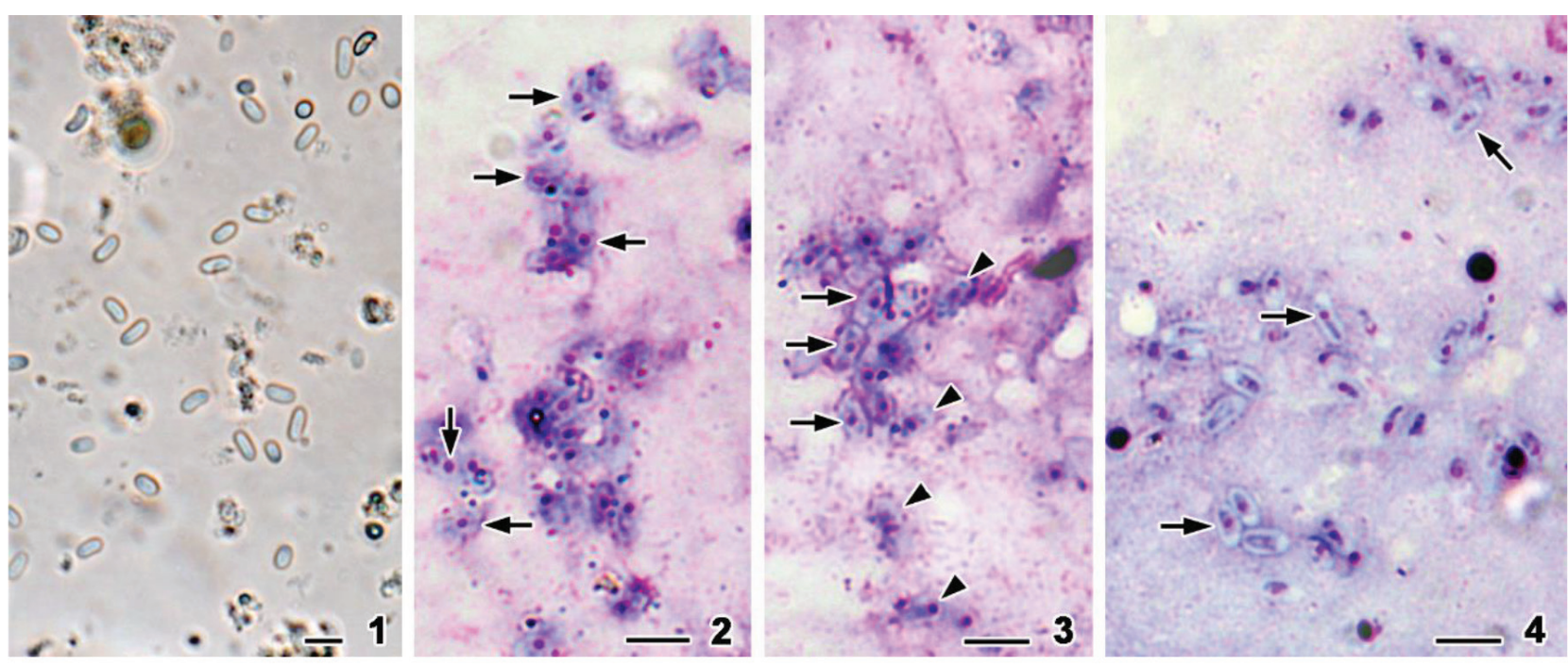

Figures 1-4. Light microscopy of fresh (1) and Giemsa-stained stages (2-4) of the new microsporidian pathogen from Crepidodera aurata. Note that all stages have unpaired nuclei (no diplokarya) and are located in direct contact with the host-cell cytoplasm and not inside parasitophorous vacuoles. 1. Fresh spores. 2. Meronts (arrows). 3. Sporonts (arrows) and sporoblasts (arrowheads). 4. Mature spores. Scale bars: $5 \mu \mathrm{m}$.

filament is isofilar and has $6-8$ coils (Figures 5,7 , and 11). The diameter of the polar filament coils is $85-95 \mathrm{~nm}$. The well-developed polaroplast has a lamellated structure with closely packed anterior lamellae and loosely packed posterior lamellae (Figures 9 and 10).

The PCR-amplified fragment of the SSU rRNA gene was sequenced. A NCBI BLAST search revealed similarities with the sequences of Nosema and Vairimorpha species. The phylogenetic tree produced three major clades. Endoreticulatus, Cystosporogenes, and Paranosema species were placed in the first group, Anncaliia and Pleistophora in the second group, and Variomorpha and Nosema species in the third group. Our isolate clustered with the Variomorpha/Nosema group. Thelohania species were placed in a separate group (Figure 12).

\section{Discussion}

Microsporidian identification requires a documenting of the developmental cycles of the pathogen and of structural characters. Therefore, microsporidia taxonomy has traditionally been based primarily on lifecycle and ultrastructural characteristics, including the fine structure of developmental stages and spores. More recently, molecular phylogeny has been included as an important means of recognizing and taxonomically assigning the species. However, the descriptions of many microsporidian species from chrysomelids have been based solely on light microscopy; only a few were also based on ultrastructural characters (Toguebaye et al., 1988; Yaman et al., 2003, 2008, 2010, 2011), and none have been characterized at the molecular level. According to the studies in the literature, microsporidia from chrysomelids have been placed into a few genera, with most species assigned to Unikaryon, Endoreticulatus, Nosema, and the unclassified genus Microsporidium (Toguebaye et al., 1988; Yaman et al., 2015). Our identification here is based on light microscopy, ultrastructural characteristics, and molecular phylogeny.

In contrast to most microsporidian spores, the pathogen infecting C. aurata has slightly curved spores. It differs in spore size (both in length and width) from other microsporidia infecting chrysomelids (see Table 2). In the lifecycle of microsporidia, the spore is the main diagnostic element, and spore shape and size are important taxonomic characteristics (Larsson, 1999; Vavra and Larsson, 1999). Light and transmission electron microscopy (Figures 2 and 9) have revealed that the microsporidian pathogen found in C. aurata is monokaryotic. Monokaryotic microsporidia in insects are found in the genera Unikaryon, Oligosporidium, Orthosomella, Canningia, Larssoniella, Endoreticulatus, Encephalitozoon, and Septata. The genera Endoreticulatus, Encephalitozoon, and Septata are characterized by the presence of a persistent vacuolar membrane between the developmental stages and the host-cell cytoplasm (Ovcharenko et al., 2013). No vacuolar membranes separating the developmental stages from the host-cell cytoplasm were observed during our microscopic studies; our isolate is therefore different from the species of these genera. Uninucleate spores in direct contact with the host-cell cytoplasm and the absence of sporophorous 

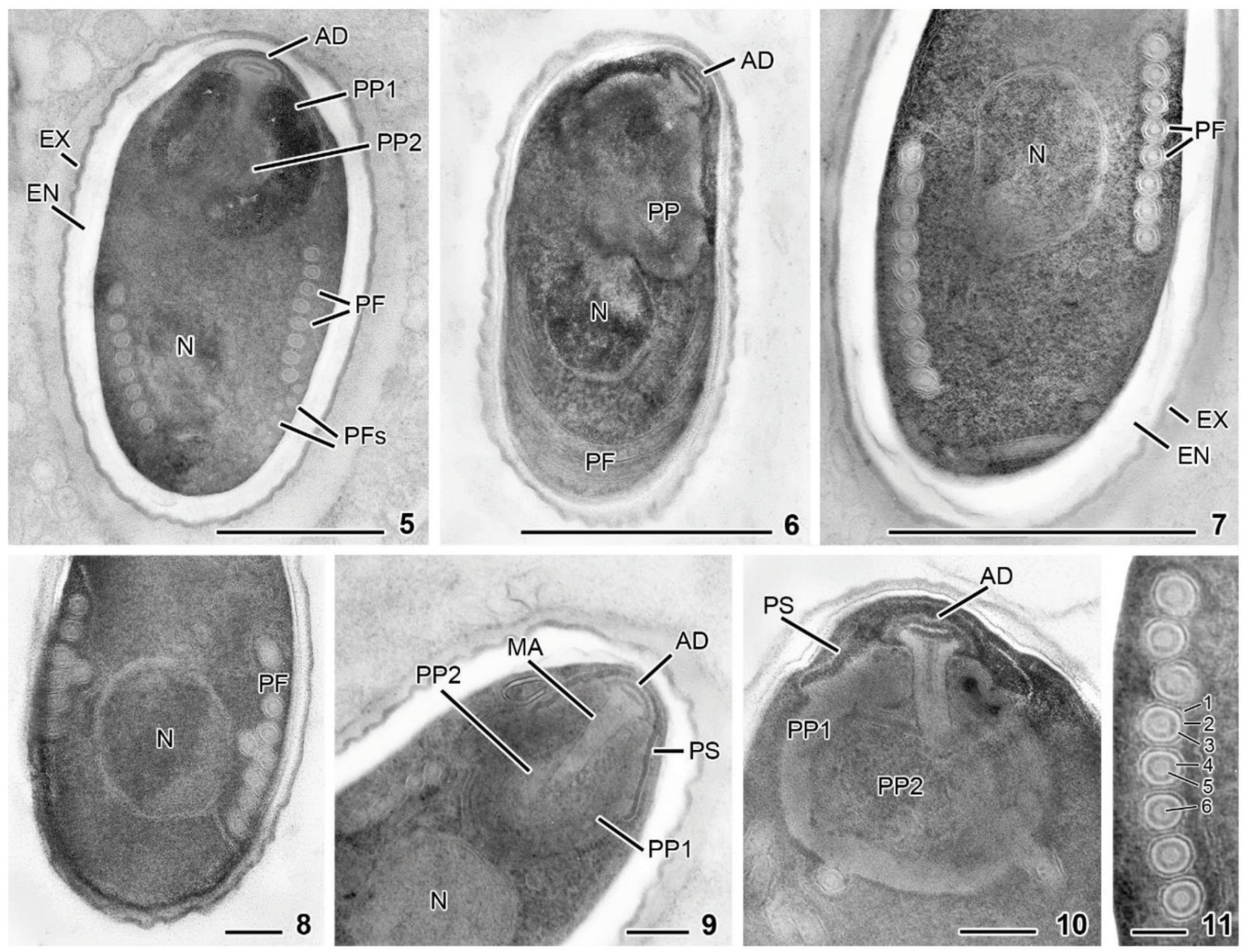

Figures 5-11. Ultrastructure of spores of the new microsporidian pathogen from Crepidodera aurata. 5-8. Longitudinal sections through the mature spores isolated from the same host species at different times. All spores have unpaired nuclei. 9, 10. Anterior part of the mature spore. Two parts of the polaroplast are noticeable. 11. Cross-section of polar filament. Six layers of the isofilar polar filament are clearly visible. AD: Anchoring disk; EN: Endospore; EX: Exospore; MA: Manubrium; N: Nucleus; PF: Polar filament; PFs: the small cross-sections of the polar filament; PP: Polaroplast; PP1: lamellar and PP2: vesicular part of the polaroplast; PS: polar sac. Scale bars: 1 $\mu \mathrm{m}$ for Figures 5-7, $0.2 \mu \mathrm{m}$ for Figures $8-10$, and $0.1 \mu \mathrm{m}$ for Figure 11 .

vesicles (pansporoblasts) are typical characteristics of monokaryotic genera such as Unikaryon, Oligosporidium, Orthosomella, Canningia, and Larssoniella. Thus, our microsporidium resembles these genera.

Microsporidia, as organisms which are well-adapted to the parasitic way of life, kill the infected host slowly by producing spores in massive numbers in the late stages of infection. Ultrastructural characters of the spore are also main diagnostic characters and are used in the classification of microsporidia (Vavra and Larsson, 1999; Yaman et al., 2011, 2016). In particular, the features of the spore are used to evaluate and compare microsporidia infecting similar host insects. The spore ultrastructure of 12 microsporidian species recorded from chrysomelid hosts has been described in the literature. Ultrastructural characteristics of the 8 Nosema and 4 Unikaryon species are given in Table 2. The number of polar coils is one of the important ultrastructural taxonomic criterions used in differentiating species (Cheung and Wang, 1995). The number of polar coils (6-8) of the microsporidian pathogen from C. aurata differs from that of 10 microsporidian species infecting chrysomelids, but it shows similarity with that of Unikaryon phyllotretae (6-7 coils) and U. nisotrae (5-7 coils). However, microsporidia are the most speciesrich. Therefore, the new isolate clearly differs from the 2 species in terms of infected host species, infection site in 


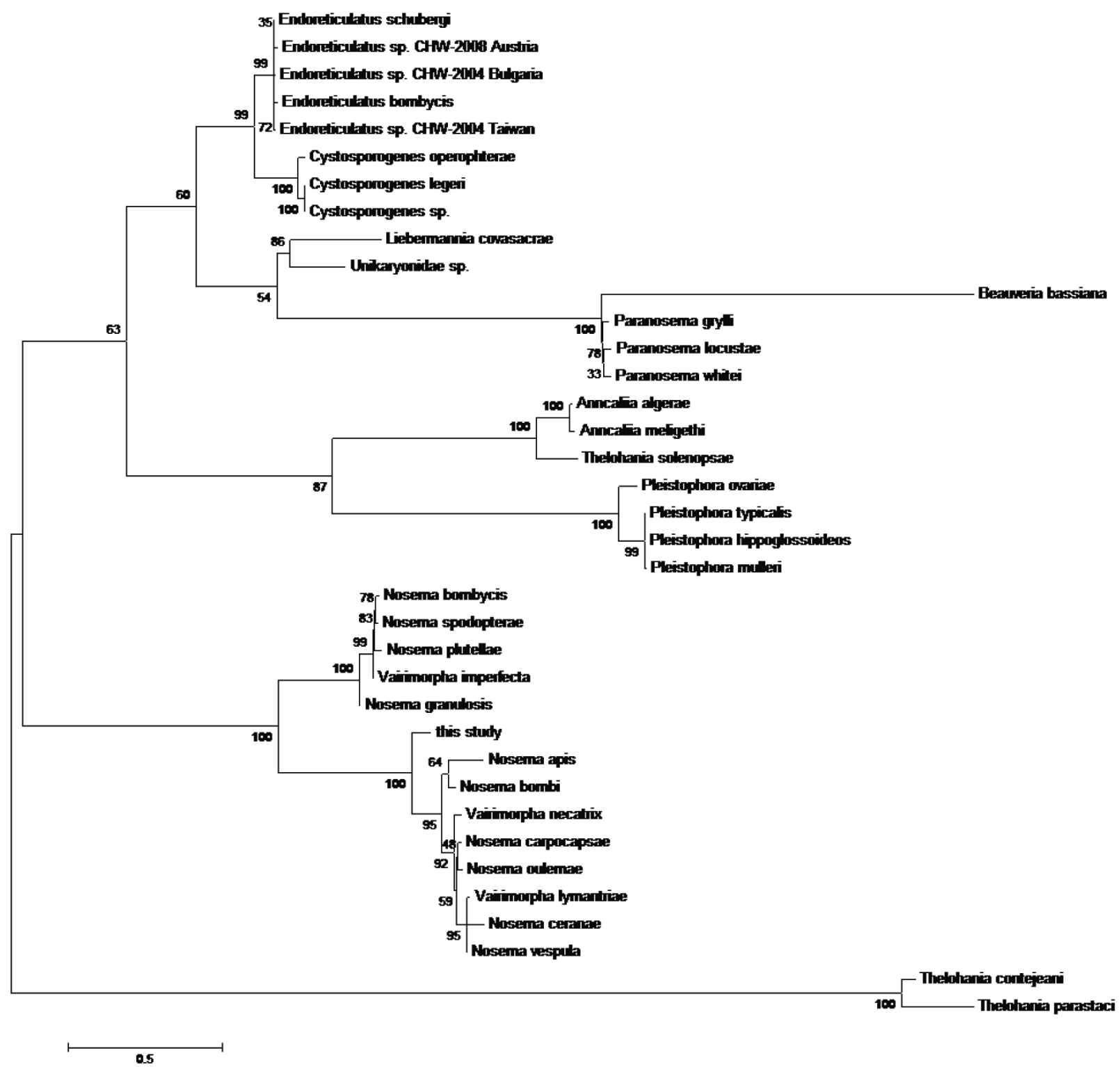

Figure 12. Phylogenetic relationships among microsporidium species isolated from different hosts based on SSUrRNA. The tree was constructed by maximum likelihood method using Kimura two-parameter distance and evaluated by 1000 bootstrap replications with the MEGA.6 program. Thelonia contejeani and Thelonia parastaci were used as outgroups in the analysis.

the host, and thickness of spore wall and spore size (Table 2). Thus, the microsporidian pathogen in C. aurata clearly differs from the described Nosema and Unikaryon species infecting chrysomelids. The new microsporidium is also different from the monokaryotic genus Endoreticulatus. It evokes a generalized infection in the host body in contrast to Endoreticulatus, which typically infects the midgut epithelium. Furthermore, we did not observe the formation of any parasitophorous vesicles by the host endoplasmic reticulum, which is a characteristic typical of the genus Endoreticulatus.
In contrast to the taxonomy based on morphological and ultrastructural features, the phylogenetic analysis of the sequences of the small subunit rRNA genes places the new microsporidium in a clade with Vairimorpha/Nosema species. These genera exhibit both monokaryotic and diplokaryotic spores, while the genus Unikaryon invariably produces mononucleated spores. We have never observed diplokaryotic sporonts dividing by binary fission to produce two diplokayotic sporoblasts and binucleate (Nosema-like) spores lying in direct contact with cytoplasm. Nor did we see monokaryotic octospores (Thelohonia-like spores) 
YAMAN et al. / Turk J Zool

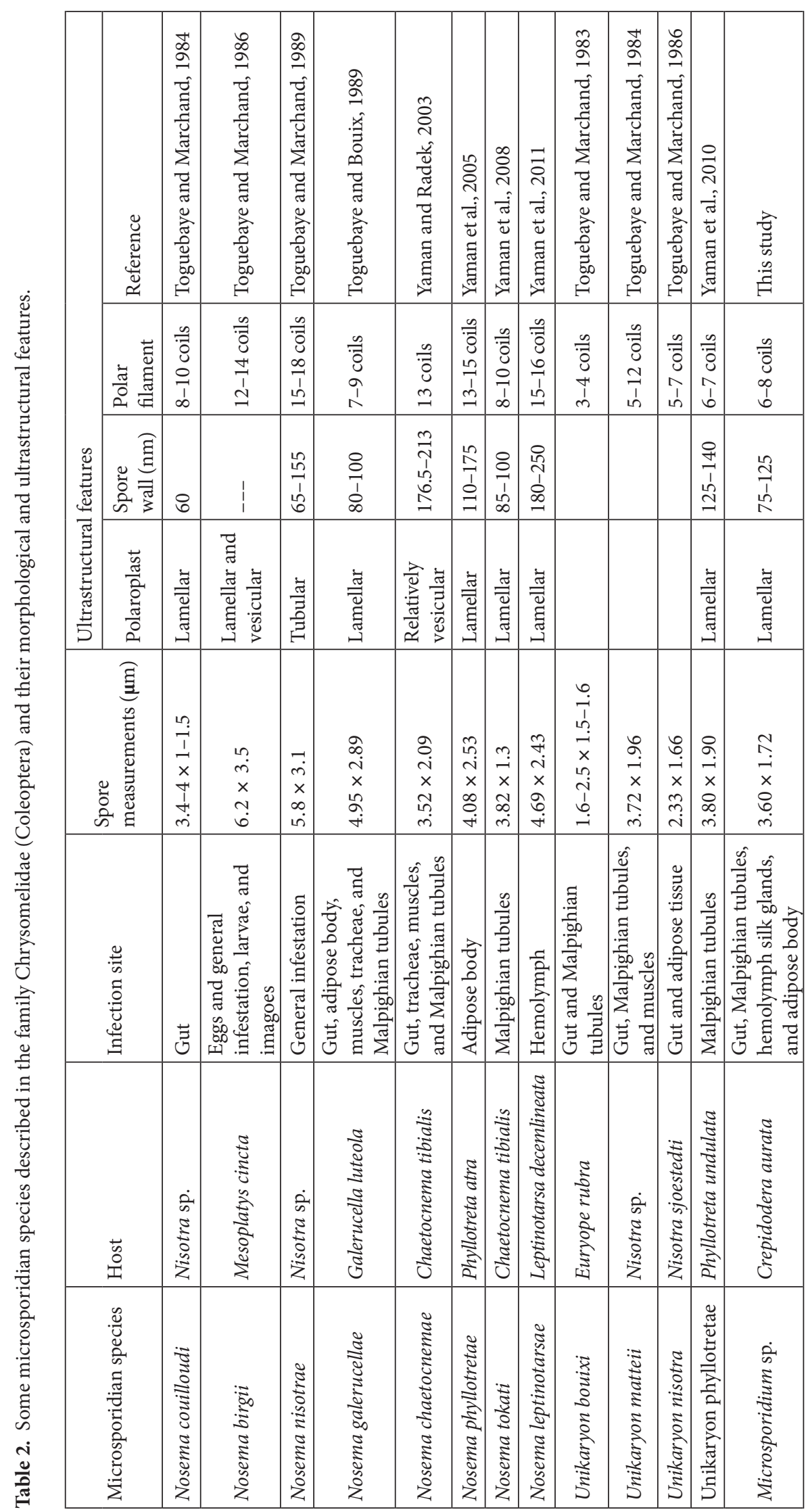


within a sporophorous vesicle, features which are typical of the genus Vairimorpha. There are more recent studies where morphological, ultrastructural, and molecular data are in conflict (Becnel et al., 2002; Ovcharenko et al., 2013). These previous molecular phylogenetic analyses have been confirmed by our results. Becnel et al. (2002) discussed a conflict between the morphological and molecular data of a microsporidium species from the mite Metaseiulus occidentalis. According to the sequence of the SSU rDNA, the mite microsporidium was most closely related to the Nosema/Vairimorpha clade, while all life cycle stages were haplokaryotic and developed in direct contact with the host-cell cytoplasm. Correspondingly, Ovcharenko et al. (2013) found that morphological and lifecycle characteristics placed their new microsporidian species (which was found in the weevil Liophloeus lentus) within the family Unikaryonidae, while the SSU rDNA phylogeny indicated that it is associated with the genus Orthosomella.

Comparison of morphological and ultrastructural characteristics and SSU rDNA sequences of our microsporidium with those of the species described

\section{References}

Aslan İ, Gruev B, Özbek H (1999). A preliminary review of the subfamily Alticinae (Coleoptera, Chrysomelidae) in Turkey. Turkish Journal of Zoology 23: 373-414.

Becnel JJ, Jeyaprakash A, Hoy MA, Shapiro A (2002). Morphological and molecular characterization of a new microsporidian species from the predatory mite Metaseiulus occidentalis (Nesbitt) (Acari, Phytoseiidae). Journal Invertebrate Pathology 79: 163 172.

Cheung WWK, Wang JB (1995). Electron microscopic studies on Nosema mesnili Paillot (Microsporidia, Nosematidae) infecting the Malpighian tubules of Pieris canidia larva. Protoplasma 186: $142-148$.

Holuša J, Lukášová K, Žižka Z, Händel U, Haidler B, Wegensteiner R (2016). Occurrence of Microsporidium sp. and other pathogens in Ips amitinus (Coleoptera, Curculionidae). Acta Parasitologica 61: 621-628.

Hyliš M, Weiser J, Oborník M, Vávra J (2005). DNA isolation from museum and type collection slides of microsporidia. Journal Invertebrate Pathology 88: 257-260.

Larsson JIR (1999). Identification of microsporidia. Acta Protozoologica 38: 161-197.

Ovcharenko M, Świątek P, Ironside J, Skalski T (2013). Orthosomella lipae sp. n. (Microsporidia) a parasite of the weevil, Liophloeus lentus Germar, 1824 (Coleoptera, Curculionidae). Journal Invertebrate Pathology 112: 33-40. for the current chrysomelid-infecting genera (Nosema, Endoreticulatus, and Unikaryon) confirms that our microsporidium is different from these. The lack of molecular data from other microsporidia which infect chrysomelids is partially responsible for the discrepancy in taxonomic placement based on morphological and molecular phylogenetic information. Therefore, we consider our microsporidium, tentatively classified as Microsporidium sp., to be a distinct, undescribed species that might even deserve the creation of a new genus in order to avoid creating an unnecessary or incorrect new genus/species. Further studies, however, are needed in order to finally resolve the taxonomic status of the distinct, undescribed microsporidia infecting different chrysomelids.

\section{Acknowledgments}

This study was financially supported by the Scientific and Technological Research Council of Turkey (TÜBİTAK112O807).

Poinar GO (1988). Nematode parasites of Chrysomelidae. In: Petitpierre E, Hsiao TH, Jolivet PH, editors. Biology of Chrysomelidae. Boston, MA, USA: Kluwer Academic Publishers, pp. 433-448.

Reynolds ES (1963). The use of lead citrate at high $\mathrm{pH}$ as an electronopaque stain in electron microscopy. Journal of Cell Biology 17: 208-212.

Spurr AR (1969). A low-viscosity epoxy resin embedding medium for electron microscopy. Journal of Ultrastructure Research 26: 31-43.

Theodorides J (1988). Gregarines of Chrysomelidae. In: Petitpierre E, Hsiao TH, Jolivet PH, editors. Biology of Chrysomelidae. Boston, MA, USA: Kluwer Academic Publishers, pp. 417-431.

Toguebaye BS, Marchand B (1983). Dévelopment d'une Microsporidie du genre Unikaryon Canning, Lei et Lie, 1974 chez un Coleoptère Chrysomelidae, Euryope rubra (Latreille, 1807): Étude ultrastructurale. Protistologica 19: 371-383.

Toguebaye BS, Marchand B (1984). Étude ultrastructurale de Unikaryon mattei n. sp. (Microsporida, Unikaryonidae) parasite de Nisotra sp. (Coleoptera, Chrysomelidae) et remarques sur la validité de certaines Nosema d'insectes. Journal of Protozoology 31: 339-346.

Toguebaye BS, Marchand B (1988). Cytologie et taxonomie d'une Microsporidie du genre Unikaryon (Microspora, Unikaryonidae) parasite du Mylabris vestita (Coleoptera, Meloidae). Canadian Journal of Zoology 66: 364-367. 
Toguebaye BS, Marchand B (1984). Nosema couilloudi n. sp., Microsporidie parasite de Nisotra sp. (Coleoptera, Chrysomelidae): Cytopathologie et ultrastructure des stades de developpement. Protistologica 20: 357-365.

Toguebaye BS, Bouix G (1989). Nosema galerucellae sp. n., microsporidian (Protozoa, Microspora), parasite of Galerucella luteola Müller (Chrysomelidae, Coleoptera): Development cycle and ultrastructure. European Journal of Protistology 24: 346-353.

Toguebaye BS, Marchand B (1986). Étude d'une infection microsporidienne due à Nosema birgii n. sp. (Microsporida, Nosematidae) chez Mesoplatys cincta Olivier, 1790 (Coleoptera, Chrysomelidae). Zeitschrift für Parasitenkund 72: 723-737.

Toguebaye BS, Marchand B (1989). Observations en microscopie électronique à transmission des stades de développement de Nosema nisotrae sp. n. (Microsporida, Nosematidae) parasite de Nisotra sp. (Coleoptera, Chrysomelidae). Archiv für Protistenkunde 137: 69-80.

Toguebaye BS, Marchand B, Bouix G (1988). Microsporidia of Chrysomelidae. In: Petitpierre E, Hsiao TH, Jolivet PH, editors. Biology of Chrysomelidae. Boston, MA, USA: Kluwer Academic Publishers, pp. 399-416.

Urban J (2011). Occurrence, bionomics and harmfulness of Crepidodera aurata (Marsh.) (Coleoptera, Alticidae). Acta Universitatis Agriculturae et Silviculturae Mendelianae Brunensis 59: 263-278.

Vavra J, Larsson JTR (1999). Structure of the microsporidia. In: Wittner M, Weiss LM, editors. The Microsporidia and Microsporidiosis. Washington, DC, USA: American Society for Microbiology, pp. 7-84.
Yaman M, Radek R (2003). Nosema chaetocnemae sp. n., a microsporidian (Microspora, Nosematidae) parasite of Chaetocnema tibialis (Chrysomelidae, Coleoptera). Acta Protozoologica 42: 231-237.

Yaman M, Radek R, Aslan I, Ertürk Ö (2005). Characteristic features of Nosema phyllotretae Weiser 1961, a microsporidian parasite of Phyllotreta atra (Coleoptera, Chrysomelidae) in Turkey. Zoological Studies 44: 368-372.

Yaman M, Radek R, Toguebaye B (2008). A new microsporidian of the genus Nosema, parasite of Chaetocnema tibialis (Coleoptera, Chrysomelidae) from Turkey. Acta Protozoologica 47: 279-285.

Yaman M, Radek R, Weiser J, Toguebaye B (2010). Unikaryon phyllotretae sp. n. (Protista, Microspora), a new microsporidian pathogen of Phyllotreta undulata (Coleoptera, Chrysomelidae). European Journal of Protistology 46: 10-15.

Yaman M, Radek R, Linde, Özcan N, Lipa JJ (2011). Ultrastructure, characteristic features and occurrence of Nosema leptinotarsae Lipa 1968, a microsporidian pathogen of Leptinotarsa decemlineata (Coleoptera, Chrysomelidae). Acta Parasitologica 56: $1-7$.

Yaman M, Alg1 G, Güner BG, Ünal S (2015). Distribution and occurrence of microsporidian pathogens of the willow flea beetle, Crepidodera aurata (Coleoptera, Chrysomelidae) in North Turkey. Entomologica Fennica 26: 171-176.

Yaman M, Güngör FP, Güner BG, Radek R, Linde A (2016). First report and spore ultrastructure of Vairimorpha plodiae (Opisthokonta, Microspora) from Plodia interpunctella (Lepidoptera, Pyralidae) in Turkey. Acta Parasitologica 61: 228-231. 